\title{
Revitalisasi Posyandu sebagai upaya peningkatan kesehatan anak dan balita di Posyandu Manggis Kelurahan Karang Roto Semarang
}

\author{
Iskim Luthfa \\ Fakultas Ilmu keperawatan, Universitas Islam Sultan Agung, Semarang, Indonesia \\ *Corresponding Author \\ Jl. Raya Kaligawe KM. 4 Semarang, Jawa Tengah, Indonesia \\ Telp. (+6224) 65833584, Fax (+6224) 6594366 \\ Email: $\underline{\text { iskim@unissula.ac.id }}$

$\begin{array}{llll}\text { Received: } & \text { Revised: } & \text { Accepted: } & \text { Published: } \\ \text { 16 October 2019 } & \text { 6 November 2019 } & \text { 18 November 2019 } & \text { 30 November 2019 }\end{array}$

\begin{abstract}
Abstrak
Sustainable Development Goals (SDGs) tahun 2016 menempatkan kesehatan ibu dan anak sebagai indikator keberhasilan dalam pembangunan kesehatan. Posyandu merupakan Pelayanan kesehatan yang memungkinkan untuk memantau kesehatan ibu dan anak, karena mampu menjangkau seluruh masyarakat sampai ke pelosok wilayah. Data dan Informasi Kesehatan Indonesia 2018, di Jawa Tengah terdapat sebanyak 46.701 Posyandu, namun yang aktif melaksanakan kegiatan hanya 33.609 Posyandu (71,97\%). Sehingga diperlukan revitalisasi posyandu yang bertujuan untuk meningkatkan fungsi dan kinerja Posyandu agar dapat memenuhi kebutuhan kesehatan masyarakat terutama anak dan balita. Program revitalisasi ini berbasis pemberdayaan, dan kader Posyandu sebagai mitranya. Kegiatan utama program revitalisasi posyandu meliputi, 1) Program pelatihan kompetensi kader, 2) Program pelayanan pokok Posyandu, dan 3) Program dukungan masyarakat. Hasil kegiatan menunjukkan kompetensi kader mengalami peningkatan meliputi pengetahuan tentang 5 program pokok posyandu, keterampilan melakukan pemeriksaan kesehatan balita, keterampilan membuat media penyuluhan kesehatan, keterampilan memberikan penyuluhan kesehatan, keterampilan melakukan kunjungan rumah, dan keterampilan melakukan pembukuan sistem informasi posyandu.
\end{abstract}

Kata kunci: kader; kesehatan anak dan balita; revitalisasi posyandu.

\begin{abstract}
One of the 2016 Sustainable Development Goals (SDGs) targets is maternal and child health as an indicator of success in health development. Posyandu is a health service that allows to monitor the health of mothers and children, being able to reach the whole community to remote areas. Indonesian Ministry of Health data for 2018, in Central Java there were 46,701 Posyandu, but only 33,609 Posyandu were active in carrying out activities (71.97\%). So that the Posyandu Revitalization is needed which aims to improve the function and performance of Posyandu so that it can meet the health needs of the community, especially children and toddlers. This revitalization program is based on empowerment, and Posyandu cadres as partners. The main activities of the Posyandu revitalization program include, 1)
\end{abstract}


Cadre competency training program, 2) Posyandu main service program, and 3) Community support program. The results of the activity showed that cadres' competencies had increased including knowledge of the five main posyandu programs, skills in conducting under-five health checks, skills in making health education media, skills in providing health education, skills in home visits, and skills in recording posyandu information systems.

Keywords: cadres; child and toddler health; posyandu revitalization

\section{PENDAHULUAN}

Kesepakatan dalam Sustainable Development Goals (SDGs) tahun 2016 menempatkan kesehatan ibu dan anak sebagai indikator keberhasilan dalam pembangunan kesehatan. Tingginya masalah kesehatan ibu dan anak yang terjadi di Indonesia, khususnya di Jawa Tengah, menunjukkan bahwa pelayanan kesehatan ibu dan anak (KIA) sangat mendesak untuk ditingkatkan baik dari segi jangkauan maupun kualitas pelayanannya.

Pelayanan kesehatan yang sangat memungkinkan untuk secara rutin memantau kesehatan ibu dan anak, serta mampu menjangkau seluruh masyarakat sampai ke pelosok wilayah adalah Pos Pelayanan Terpadu (Posyandu). Posyandu dibentuk oleh masyarakat desa/kelurahan di bawah bimbingan petugas kesehatan dari Puskesmas setempat dengan tujuan untuk mendekatkan pelayanan kesehatan dasar, terutama Kesehatan Ibu dan Anak (KIA), Keluarga Berencana (KB), imunisasi, gizi dan penanggulangan diare.

Secara kuantitas, perkembangan jumlah posyandu sangat menggembirakan, satu desa bisa dijumpai dua sampai tiga Posyandu. Namun ditinjau dari aspek kualitas ternyata jumlah Posyandu yang aktif melaksanakan kegiatan pelayanan lima program pokok masih rendah. Data dan Informasi Kesehatan Indonesia tahun 2017 menunjukkan bahwa Posyandu jumlah Posyandu di Indonesia mencapai 294.428 posyandu, dan yang aktif melaksanakan kegiatan posyandu sebanyak 169.087 (57,43\%). Data dan Informasi Kesehatan Indonesia tahun 2018, di Jawa Tengah terdapat sebanyak 46.701 Posyandu, namun yang aktif melaksanakan kegiatan hanya 33.609 Posyandu (71,97\%) (Kemenkes RI, 2018)

Meningkatnya jumlah Posyandu yang tidak diimbangi dengan peningkatan kualitasnya, dapat berdampak pada rendahnya target keberhasilan pencapaian kesehatan ibu dan anak. Hal ini dibuktikan dari data Profil Kesehatan Indonesia tahun 2015 yang menunjukkan cakupan penimbangan balita di Posyandu masih 67,87\% dari target $80 \%$, dan cakupan pelayanan kesehatan anak balita masih $78,11 \%$ dari target $90 \%$.

Penyebab utama rendahnya kualitas pelayanan di Posyandu adalah kader sebagai pelaksana Posyandu tidak memiliki kompetensi yang cukup. Kader tidak memiliki pengetahuan dan keterampilan yang memadai untuk memberikan pelayanan kesehatan (Nelty, 2012). Hal ini sejalan dengan penelitian yang dilakukan oleh Prabowo, Zulaikha dan Luthfa (2012) yang menemukan bahwa ada hubungan antara pengetahuan Kader dengan pelaksanaan kegiatan Posyandu di Puskesmas Lamper Tengah Semarang, dimana semakin tinggi pengetahuan Kader maka pelaksanaan kegiatan Posyandu semakin aktif.

Penelitian lainnya yang dilakukan oleh Isaura (2011) menunjukkan bahwa ada hubungan antara pengetahuan dengan kinerja Kader dimana Kader yang memiliki pengetahuan rendah maka kinerjanya juga rendah. Penelitian lainnya dilakukan oleh beberapa peneliti (Sandiyani, 2011; Prang, Pangemanan dan Tilaar, 2013; Syafei, 2010) menunjukkan bahwa faktor internal yang mempengaruhi kinerja kader antara lain: umur, lama menjadi kader, dan pengetahuan kader. Sedangkan faktor eksternal yang berpengaruh terhadap kinerja kader antara lain: dukungan tokoh masyarakat, sarana yang tersedia di Posyandu, pelatihan yang diikuti oleh Kader, dan pembinaan yang dilakukan oleh petugas kesehatan. 
Mitra dalam kegiatan PKM ini yaitu Posyandu Manggis yang berada di RW IV Kelurahan Karang Roto Semarang, merupakan binaan dari Puskesmas Bangetayu Semarang. Posyandu ini memiliki kader sebanyak 15 orang, namun yang aktif hanya 10 orang. RW IV terbagi menjadi 8 RT dengan jumlah balita sebanyak 74 orang. Berdasarkan analisis situasi beberapa permasalahan mitra antara lain Pengetahuan Kader tentang Posyandu relatif masih rendah, kelima program pokok posyandu belum dilaksanakan secara optimal, cakupan pelayanan Posyandu belum mencapai target $80 \%$ kunjungan balita, serta sarana prasarana penunjang pelaksanaan Posyandu belum lengkap.

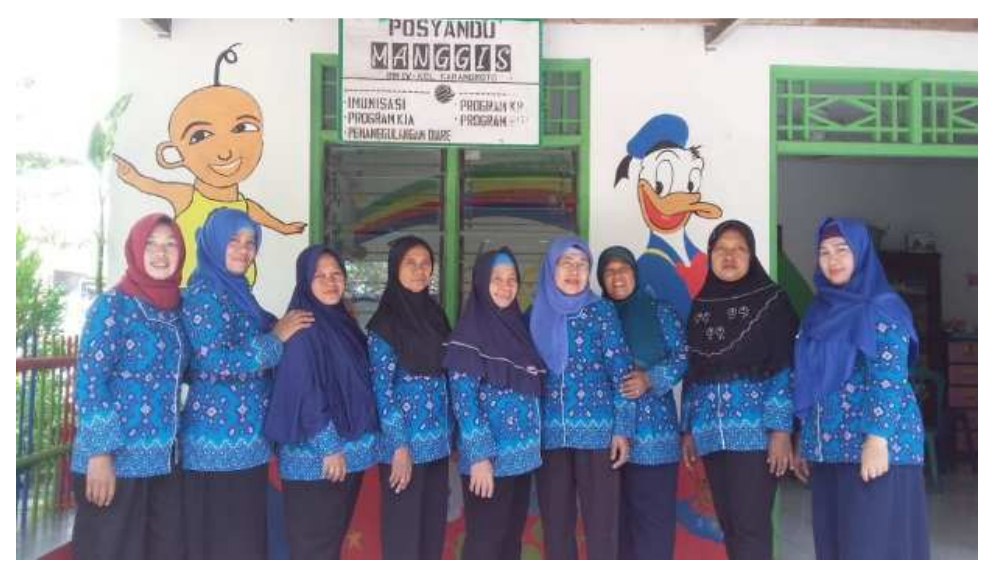

Gambar 1. Mitra Kegiatan PKM

Beberapa pertimbangan pengabdian masyarakat ini diarahkan untuk memberikan pelatihan dan pendampingan Kader Posyandu berdasarkan pada beberapa saran dari penelitianpenelitian yang sudah dipublikasikan antara lain, penelitian yang dilakukan oleh Nugroho (2008) dan Evita (2009) yang menyarankan untuk dapat meningkatkan kinerja kader maka perlu dilakukan kegiatan pelatihan bagi kader Posyandu. Demikian pula saran dari Puspasari (2012) upaya untuk mengatasi permasalahan Kader yang dapat menurunkan kinerjanya maka perlu diadakan kerja sama dengan instansi terkait (institusi pendidikan kesehatan) serta perlu adanya pembinaan kader secara rutin oleh pihak Puskesmas.

Mengacu pada Peraturan Menteri Dalam Negeri (Permendagri) Nomor 9 tahun 1990 yang menginstruksikan bahwa masyarakat bersama dengan pemerintah daerah bertanggungjawab untuk melakukan peningkatan pembinaan mutu Posyandu. Hal ini dirasa perlu untuk kemudian perguruan tinggi kesehatan melibatkan diri dalam pembinaan dan pendampingan Posyandu di wilayahnya. Tujuan dari kegiatan pengabdian kepada masyarakat ini adalah supaya pengetahuan dan keterampilan Kader meningkat sehingga kualitas pelayanan Posyandu juga akan meningkat, dan pada akhirnya derajat kesehatan anak dan balita akan meningkat.

\section{METODE}

Kegiatan pengabdian kepada masyarakat ini menggunakan beberapa metode pendekatan yang dilakukan secara bersama-sama yaitu:

1. Berbasis kelompok kader, seluruh kegiatan pengabdian masyarakat ini dilakukan dengan menggunakan kelompok sebagai media belajar. Perencanaan, pendampingan, monitoring dan evaluasi seluruh kegiatan masyarakat dilakukan secara bersama-sama.

2. Konprehensif, seluruh kegiatan pengabdian masyarakat ini dilakukan secara berkesinambungan, mulai dari penyiapan SDM, penyediaan kelengkapan sarana prasarana dan dukungan dari pihak luar. 
3. Berbasis empowering (pemberdayaan), kegiatan pengabdian masyarakat ini berupaya menggali potensi masyarakat untuk diberdayakan sebagai kader kesehatan. Karena menyangkut kesehatan masyarakat maka kader yang berasal dari warga setempat akan lebih peka dan peduli melalui pelatihan dan pendampingan pelaksanaan Posyandu.

Selanjutnya ketiga metode di atas diimlementasikan dalam 4 (empat) tahapan yaitu (1) sosialisasi, (2) peningkatan kompetensi, (3) pelaksanaan kegiatan serta (4) monitoring dan evaluasi.

\section{HASIL DAN PEMBAHASAN}

Kegiatan pengabdian kepada masyarakat ini dilaksanakan di Posyandu Manggis Kelurahan Karang Roto Semarang, selama empat bulan sejak april sampai dengan juli 2019 meliputi empat tahapan. Tahap pertama kegiatan pengadian kepada masyarakat ini yaitu sosialisasi. Kegiatan sosialisasi dilaksanakan dengan melibatkan seluruh kader posyandu. Hasil dari kegiatan sosialisasi yang dilakukan yaitu seluruh kader Posyandu memahami serangkaian kegiatan program PKM yang akan dilaksanakan, bersedia mengikuti dan berkomitmen mencapai target dan luaran PKM. Kegiatan sosialisasi juga disampaikan kepada pihak Puskesmas Bangetayu Semarang, hasilnya Puskesmas memberikan dukungan penuh terhadap kegiatan PKM yang akan dilakukan dan bersedia melakukan pendampingan.

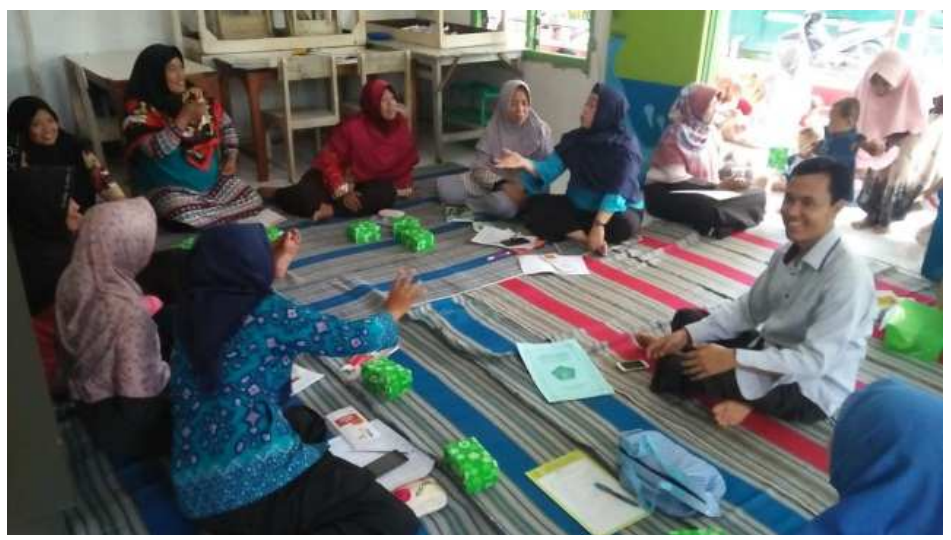

Gambar 2. Sosialisasi Kegiatan PKM

Tahap kedua, yaitu peningkatan kompetensi kader. Kegiatan peningkatan kompetensi kader dilakukan melalui pelatihan revitalisasi posyandu. Hasil dari kegiatan ini kader Posyandu Manggis menguasai lima program pokok Posyandu, pelaksanaan Posyandu melalui lima meja, dan menguasai pembukuan sistem informasi Posyandu (SIP). Kader Posyandu Manggis menguasai pemeriksaan kesehatan pada balita, memiliki keterampilan membuat media dan memberikan penyuluhan kesehatan, serta memiliki kemampuan melakukan kunjungan rumah. 


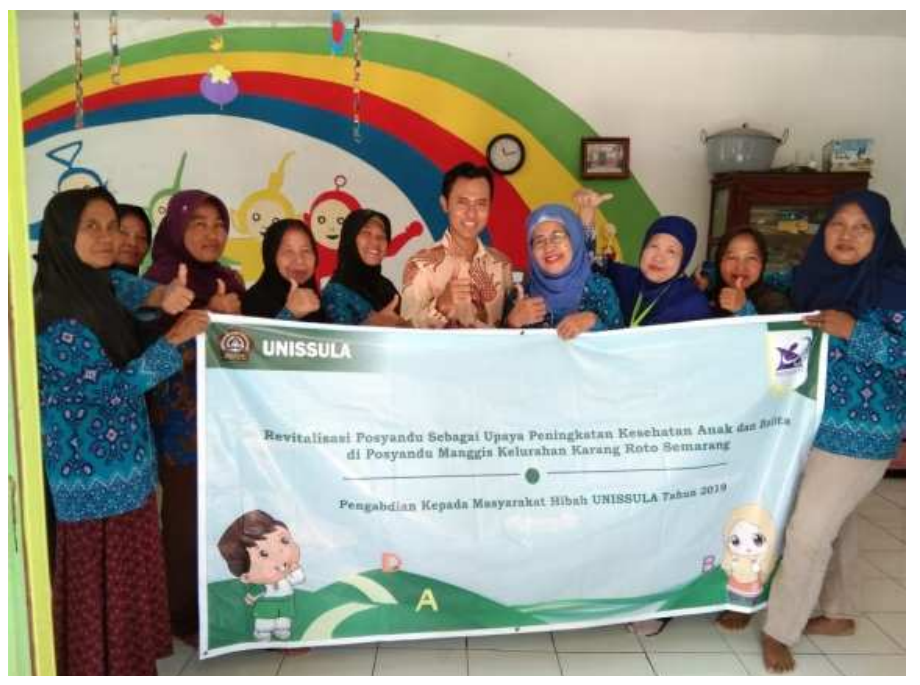

Gambar 3. Pelatihan Revitalisasi Posyandu

Tahap ketiga yaitu pelaksanaan kegiatan posyandu. Pelaksanaan posyandu sudah secara rutin dilaksanakan sebulan sekali. Hasil dari pelaksanaan Posyandu dijelaskan pada tabel 1.

Tabel 1. Pelaksanaan Posyandu Manggis

\begin{tabular}{clcc}
\hline No & \multicolumn{1}{c}{ Keterangan } & Pre Test & Post Test \\
\hline 1 & $\begin{array}{l}\text { Pengetahuan Kader tentang } \\
\text { program pokok Posyandu }\end{array}$ & $60 \%$ & $90 \%$ \\
\hline 2 & $\begin{array}{l}\text { Keterampilan kader melakukan } \\
\text { pemeriksaan kesehatan balita }\end{array}$ & $40 \%$ & $70 \%$ \\
\hline 3 & $\begin{array}{l}\text { Kemampuan kader membuat } \\
\text { media penyuluhan kesehatan }\end{array}$ & $10 \%$ & $70 \%$ \\
\hline 4 & $\begin{array}{l}\text { Keterampilan kader melakukan } \\
\text { penyuluhan kesehatan }\end{array}$ & $40 \%$ & $80 \%$ \\
\hline 5 & $\begin{array}{l}\text { Keterampilan kader melakukan } \\
\text { kunjungan rumah }\end{array}$ & $30 \%$ & $80 \%$ \\
\hline 6 & $\begin{array}{l}\text { Kemampuan kader melakukan } \\
\text { pembukuan SIP }\end{array}$ & $30 \%$ & \\
\hline
\end{tabular}

Tahap keempat, yaitu monitoring dan evaluasi. Monitoring dilakukan selama 3 bulan dengan metode pendampingan pada saat kegiatan Posyandu. Evaluasi merupakan tahapan akhir dari kegiatan pengabdian masyarakat, bertujuan untuk mengetahui kualitas pelaksanaan kegiatan Posyandu dan cakupan balita yang berkunjung (Sari, 2018). Hasil dari evaluasi berupa kegiatan Posyandu sudah berjalan sebulan sekali dengan lima program pokok Posyandu dan dihadiri oleh pembina wilayah dari Puskesmas Bangetayu Semarang. Cakupan Posyandu dilihat dari jumlah balita dan anak yang berkunjung sudah mencapai $90 \%$.

Posyandu merupakan tombak pelayanan kesehatan yang paling ujung yang mampu menjangkau seluruh lapisan masyarakat. Program ini merupakan strategi pemerintah dalam jangka panjang untuk menurunkan angka kematian bayi dan angka kematian ibu, serta menekan angka kelahiran. Melalui program Posyandu tenaga professional dari petugas kesehatan bekerjasama dengan masyarakat untuk bersama-sama menanggulangi masalah kesehatan masyarakat, terutama upaya untuk menurunkan angka kematian balita dan anak. 
Data dari Kementerian Kesehatan pada tahun 2016 jumlah posyandu yang tersebar di seluruh Indonesia mencapai 268.439. Namun jika ditinjau dari segi kualitasnya masih banyak Posyandu yang memiliki masalah antara lain sarana prasarana yang belum memadai, rendahnya kompetensi kader dalam menjalankan program posyandu, minimnya pendampingan dan pembinaan baik dari Pemerintahan Desa dan dinas/instansi lembaga terkait, yang kemudian mengakibatkan rendahnya kunjungan masyarakat ke Posyandu.

Revitalisasi posyandu merupakan gerakan masyarakat untuk meningkatkan status kesehatan khususnya anak dan balita (Ulfa, 2018). Kegiatan revitalisasi posyandu menggunakan beberapa metode pendekatan, pertama berbasis kelompok kader. Kader merupakan pilar utama penggerak pelaksanaan kegiatan posyandu. Kader sebaiknya berasal dari warga masyarakat setempat yang memahami wilayah kerjanya dan dinilai mampu bekerja secara sukarela mengelola posyandu. Sebenarnya tidak ada syarat khusus untuk menjadi seorang kader, yang terpenting bisa membaca dan menulis, memiliki waktu luang, mau bekerja secara sukarela dan ikhlas. Menjadi seorang kader posyandu juga tidak memiliki batas periode waktu, selama masih bersedia menjadi kader maka bisa dipilih kembali.

Metode kedua, yaitu komprehensif, seluruh rangkaian kegiatan revitalisasi posyandu secara berkesinambungan diarahkan untuk perbaikan kualitas pelayanan posyandu, mulai dari penyiapan SDM dan penyediaan kelengkapan sarana prasarana pendukung. Hal ini sesuai dengan hasil penelitian yang dilakukan oleh Arwinda, Arifin dan Herawati (2014) menunjukkan hasil terdapat hubungan ketersediaan sarana dengan pelaksanaan posyandu di wilayah kerja Puskesmas di Kota Banjarbaru. Setiap kegiatan posyandu pastinya membutuhkan peralatan dan perlengkapan kerja yang memadai sehingga kegiatannya dapat berjalan dengan optimal tanpa mengalami hambatan. Beberapa perlengkapan Posyandu meliputi Kartu Menuju Sehat (KMS), Pita Lingkar Lengan Atas (LILA), Media Komunikasi Informasi dan Edukasi (KIE), obatobatan dasar dan sebagainya.

Metode ketiga, yaitu berbasis empowering (pemberdayaan), kegiatan pengabdian masyarakat ini berupaya menggali potensi masyarakat untuk diberdayakan sebagai kader kesehatan. Karena menyangkut kesehatan masyarakat maka kader yang berasal dari warga setempat akan lebih peka dan peduli. Melalui pelatihan dan pendampingan pelaksanaan Posyandu. Hal ini sejalan dengan penelitian yang dilakukan oleh Zainiah, N. dan Suratini (2014) hasil penelitian menunjukkan bahwa ada hubungan antara pelatihan dengan tingkat keterampilan kader dalam pelayanan Posyandu.

Pelatihan merupakan salah satu intervensi yang bertujuan untuk meningkatkan pengetahuan dan keterampilan. Melalui pelatihan, kader diberikan materi terkait informasi tentang program pokok posyandu, dan pemantauan tumbuh kembang balita termasuk pemeriksaan fisik balita. Selain menggunakan metode ceramah, metode demonstrasi juga diterapkan dimana kader diajarkan cara membuat media dan praktik secara langsung memberikan penyuluhan kesehatan, kader juga secara langsung praktik kunjungan rumah ibu yang punya balita, serta praktik melakukan pembukuan di KMS dan buku SIP (Sistem Informasi Posyandu).

Kegiatan pengabdian masyarakat ini diarahkan untuk meningkatkan pengetahuan dan keterampilan para kader. Pada tabel 1 diketahui setelah dilakukan pelatihan pengetahuan kader tentang 5 program pokok Posyandu meningkat dari $60 \%$ menjadi $90 \%$, Keterampilan kader melakukan pemeriksaan kesehatan balita meningkat dari $40 \%$ menjadi $70 \%$, Kemampuan kader membuat media penyuluhan kesehatan meningkat dari $10 \%$ menjadi $70 \%$, Keterampilan kader melakukan penyuluhan kesehatan meningkat dari $30 \%$ menjadi $80 \%$, Keterampilan kader melakukan kunjungan rumah meningkat dari $30 \%$ menjadi $80 \%$, dan kemampuan kader melakukan pembukuan SIP meningkat dari 30\% menjadi $80 \%$.

Hasil kegiatan pengabdian masyarakat ini sejalan dengan beberapa penelitian sebelumnya, antara lain Lubis, Z. dan Syahri, I.M. (2015) hasil penelitian menunjukkan ada 
pengaruh pelatihan kader terhadap tingkat pengetahuan dan tindakan kader dalam menilai dan memantau pertumbuhan balita.

Keberhasilan kader dalam melaksanakan program posyandu tentunya memerlukan dukungan penuh dari berbagai pihak baik dukungan moril, dukungan materiil dan dukungan finansial. Selain itu perlunya kerjasama dengan Puskesmas sebagai Pembina wilayah sehingga senantiasa mendapatkan bimbingan dan pemantauan dari petugas kesehatan. Keberhasilan posyandu dalam melaksanakan program pokok kesehatan akan memberikan kontribusi yang besar dalam meningkatkan kesehatan anak dan balita.

\section{KESIMPULAN}

Kesimpulan dari kegiatan pengabdian masyarakat yang telah dilakukan adalah; 1) Meningkatnya pengetahuan Kader tentang 5 program pokok Posyandu dari $60 \%$ menjadi $90 \%$, 2) Meningkatnya keterampilan kader dalam melakukan pemeriksaan kesehatan balita dan anak dari $40 \%$ menjadi $70 \%$, 3) Meningkatnya kemampuan kader membuat media penyuluhan kesehatan dari $10 \%$ menjadi $70 \%$, 4) Meningkatnya keterampilan kader melakukan penyuluhan kesehatan dari $30 \%$ menjadi $80 \%$, 5) Meningkatnya keterampilan kader melakukan kunjungan rumah dari $30 \%$ menjadi $80 \%$, dan 6) Meningkatnya kemampuan kader melakukan pembukuan SIP dari $30 \%$ menjadi $80 \%$.

Saran untuk kegiatan pengabdian masyarakat revitalisasi Posyandu adalah: 1) Kader mengikuti kegiatan pelatihan secara aktif dan berusaha mengaplikasikan keterampilan yang didapat, 2) Puskesmas sebagai Pembina wilayah secara intensif memberikan dukungan dan secara berkala melakukan pembinaan pelaksanaan Posyandu, 3) Masyarakat dan pemerintahan desa bersama-sama mendukung kegiatan Posyandu dengan cara meningkatkan kesadaran untuk berkunjung ke Posyandu.

\section{UCAPAN TERIMA KASIH}

Tim pelaksana kegiatan pengabdian masyarakat mengucapkan terima kasih kepada seluruh kader Posyandu Manggis di Karang Roto Semarang yang telah bersedia menjadi mitra dalam pelaksanaan kegiatan ini, Lembaga Penelitian dan Pengabdian Masyarakat (LPPM) UNISSULA yang telah mendanai kegiatan ini, seluruh civitas akademika Fakultas Ilmu Keperawatan Unissula yangs enantiasa memberikan dukungannya, serta semua pihak terkait lainnya yang telah membantu pelaksanaan pengabdian masyarakat ini.

\section{DAFTAR PUSTAKA}

Arwinda, R., Arifin, S. dan Herawati (2014). Hubungan ketersediaan sarana dengan pelaksanaan posyandu pada wilayah kerja Puskesmas di Kota Banjarbaru. Jurnal Dunia Keperawatan, Vol 2, 55-60.

Evita, D. (2009). 'Pengaruh Pelatihan terhadap Pengetahuan, Keterampilan, Kepatuhan Kader Posyandu dalam Menerapkan Standar Pemantauan Pertumbuhan Balita di Kota Bitung Sulawesi Utara'. Repository UGM.ac.id.

Isaura, V. (2011). Faktor-faktor yang berhubungan dengan kinerja Kader Posyandu di wilayah kerja Puskesmas Tarusan Kecamatan Koto XI Tarusan Kabupaten Pesisir Selatan. Repository.unand.ac.id.

Lubis, Z. dan Syahri, I.M. (2015) Pengetahuan dan tindakan kader posyandu dalam pemantauan pertumbuhan anak balita. Jurnal Kesehatan Masyarakat, 11(1), 65-73. 
Nelty, N. R. (2012). Tingkat Pengetahuan Kader tentang Pos Pelayanan Terpadu (POSYANDU) di Desa Kadilanusukoharjo. Repository Stikes Kusuma Husada Surakarta.

Nugroho, H. A. (2008). Hubungan antara Pengetahuan dan Motivasi Kader Posyandu dengan Keaktifan Kader Posyandu di Desa Dukuh Tengah Kecamatan Ketanggungan Kabupaten Brebes. Fikkes Jurnal Keperawatan, vol. 2, no. 1, hh.1-8.

Prabowo, R.K., Zulaikha, S.T. dan Luthfa, I. (2012). Hubungan antara pengetahuan Kader Posyandu dengan pelaksanaan kegiatan Posyandu di wilayah kerja Puskesmas Lamper Tengah Semarang. Unissula.ac.id.

Prang, R., Pangemanan, J.M., dan Tilaar, C. (2013). Faktor-Faktor Yang Berhubungan Dengan Keaktifan Kader Posyandu di Wilayah Kerja Puskesmas Tareran Kecamatan Tareran Kabupaten Minahasa Selatan. fkm.unsrat.ac.id.

Puspasari, A. (2012). Faktor-faktor yang Mempengaruhi Kinerja Kader Posyandu di Kota Sabang Propinsi Nanggroe Aceh Darussalam'. Repository IPB.ac.id.

Sandiyani, R. A. (2011). Lama Menjadi Kader, Frekuensi Pelatihan, Pengetahuan Gizi, dan Sikap Kader Posyandu dengan Perilaku Penyampaian Informasi tentang Pesan Gizi Seimbang. Universitas Diponegoro Semarang.

Sari, P. (2018). Evaluasi pelaksanaan revitalisasi posyandu dan pelatihan kader sebagai bentuk pengabdian masyarakat (studi kasus di rw 06 desa cileles kecamatan jatinangor tahun 2017). Jurnal Unpad, vol 2(2), 1-5.

Syafei, A. (2010). 'Faktor-Faktor yang Berhubungan dengan Partisipasi Kader dalam Kegiatan Gizi di Posyandu di Kelurahan Rengas Kecamatan Ciputat Timur Kota Tangerang Selatan'. Repository UIN Syarif Hidayatullah.ac.id.

Ulfa, S.L. (2018). Strategi revitalisasi posyandu dalam pengembangan fungsi dan kinerja posyandu di uptd puskesmas sandar angin kelurahan reba tinggi kecamatan dempo utara kota pagaralam. Digilib.unila.ac.id.

Zainiah, N. dan Suratini (2014). Hubungan frekuensi pelatihan yang diikuti kader dengan tingkat keterampilan kader dalam pelayanan posyandu balita di desa Nogotirto Gamping Sleman Yogyakarta. digilib.unisayogya.ac.id. 